\title{
http://dx.doi.org/10.18778/2080-8313.18.03
}

Tom XVIII

Aleksandra Arkusz

(Uniwersytet Jagielloński)

\section{ŻYCIE CODZIENNE OBYWATELI POLSKICH W WYBRANYCH OBOZACH W ZSRR W LATACH 1944-1949}

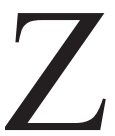
chwilą ponownego wkroczenia Armii Czerwonej na Kresy Wschodnie II RP w styczniu 1944 r. rozpoczęła się kolejna faza represji radzieckich wobec obywateli polskich. Działania Ludowego Komisariatu Spraw Wewnętrznych (NKWD) ZSRR, Ludowego Komisariatu Bezpieczeństwa Państwowego (NKGB) ZSRR, jednostek kontrwywiadu „Smiersz” Ludowego Komisariatu Obrony ZSRR, a także Armii Czerwonej skierowane były przeciwko polskiemu podziemiu niepodległościowemu. Zatrzymaniom podlegali zarówno żołnierze Armii Krajowej (AK), jak i działacze pionu administracyjnego oraz politycznego Polskiego Państwa Podziemnego. Proces likwidacji polskiego podziemia prowadzony był równolegle $\mathrm{z}$ instalowaniem na ziemiach polskich organów władzy podporządkowanych bezpośrednio Moskwie. Działania te były odzwierciedleniem polityki Józefa Stalina wobec Polski, która w nowych granicach (pozbawiona Kresów Wschodnich) miała znaleźć się w orbicie politycznych wpływów Kremla. Represje wymierzone w polskie struktury niepodległościowe, traktowane jako programowo antyradzieckie, miały również na celu sianie terroru i zastraszanie ludności cywilnej, stanowiącej oparcie dla członków podziemia ${ }^{1}$.

Aresztowania przeprowadzano zarówno na terenach inkorporowanych do ZSRR w 1939 r., jak i na obszarze Polski ,pojałtańskiej”. Osoby zatrzymane na Kresach Wschodnich, z wyjątkiem Lwowa i Wileńszczyzny do zimy 1945 r., były najczęściej skazywane, zaś zdecydowaną większość zatrzymanych na terenach na zachód od linii Curzona internowano, a więc pozbawiono wolności bez wyroku

${ }^{1}$ NKWD i polskie podziemie 1944-1945.Z, „teczek specjalnych” J.W. Stalina, red. A.F. Noskowa, A. Fitowa, Kraków 1998, s. 14; P. Aptekar, Walka wojsk wewnętrznych NKWD z polskim podziemiem zbrojnym i deportowanie jego członków do ZSRR przez wojska konwojowe (na podstawie dokumentów $z$ Rosyjskiego Państwowego Archiwum Wojskowego), [w:] NKWD o Polsce i Polakach. Rekonesans archiwalny, red. W. Materski, A. Paczkowski, Warszawa 1996, s. 53; P. Kołakowski, NKWD i GRU na ziemiach polskich 1939-1945, Warszawa 2002, s. 221. 
jakiegokolwiek organu sądowego ${ }^{2}$. Internowanym nie przedstawiono formalnych zarzutów oraz nie im podano przyczyn zatrzymania i wywiezienia do obozów.

Dla internowanych żołnierzy polskiego podziemia niepodległościowego już w 1944 r. wyznaczono trzy główne obozy stacjonarne podległe Głównemu Zarządowi do Spraw Jeńców Wojennych i Osób Internowanych (GUPWI) NKWD ZSRR. Były to: obóz nr 41 w Ostaszkowie, obóz nr 178-454 w Riazaniu oraz obóz $\mathrm{nr} 270 \mathrm{w}$ Borowiczach. Łącznie w latach 1944-1949 przetrzymywano w nich 8587 żołnierzy AK. Obozy te różniły się nie tylko kontyngentem uwięzionych, ale także warunkami bytowymi. W niniejszym artykule opisano dwa z nich - obóz riazański oraz obóz borowicki, a także obóz w Charkowie podległy Wydziałowi Kontrwywiadu „Smiersz” Charkowskiego Okręgu Wojskowego. Obozy te były ze sobą powiązane. Cały kontyngent uwięziony w Charkowie po pewnym czasie wysłano bowiem do obozu w Riazaniu, a część kontyngentu riazańskiego do obozu w Borowiczach.

\section{Obóz w Charkowie}

W obozie w Charkowie we wrześniu-październiku 1944 r. umieszczono wyselekcjonowaną grupę 134 Polaków (128 mężczyzn i sześć kobiet) zatrzymanych przez radziecką policję polityczną i jednostki Armii Czerwonej w drugiej połowie tamtego roku. Byli to wysocy rangą przedstawiciele Delegatury Rządu RP na Kraj z województw: białostockiego, lubelskiego, lwowskiego i tarnopolskiego. W obozie tym znaleźli się m.in.: generał brygady Ludwik Bittner, ps. Halka - dowódca 9. Podlaskiej Dywizji Piechoty AK; Władysław Cholewa, ps. Jan Paśnik - Delegat Rządu RP na Okręg Lubelski; podpułkownik Stefan Czerwiński, ps. Stefan Zamkowski - komendant Okręgu Lwowskiego AK oraz dowódca 5. Dywizji Piechoty AK; generał (w rzeczywistości pułkownik) Władysław Filipkowski, ps. Janka - komendant Obszaru Lwowskiego AK; major Tadeusz Sztumberk-Rychter, ps. Żegota - szef sztabu, a następnie również p.o. dowódcy 27. Wołyńskiej Dywizji Piechoty AK; generał (w rzeczywistości pułkownik) Adam Świtalski, ps. Dąbrowa - dowódca 3. Dywizji Piechoty AK oraz generał (w rzeczywistości pułkownik) Kazimierz Tumidajski, ps. Marcin - komendant Okręgu Lublin $\mathrm{AK}^{3}$.

Już sam sposób transportu więźniów do obozu odbiegał zasadniczo od praktyk stosowanych przez stronę radziecką. Przewożono ich bowiem w wielkiej konspiracji, najczęściej samolotami w kilkunastoosobowych grupach. Budynek, w którym przetrzymywano Polaków, znajdował się w oddalonej od centrum

\footnotetext{
${ }^{2}$ Represje sowieckie wobec Polaków i obywateli polskich, oprac. S. Ciesielski, W. Materski, A. Paczkowski, Warszawa 2002, s. 24-25.

3 A. Arkusz, Obywatele polscy w obozie kontrwywiadu ,Smiersz" w Charkowie w latach 19441945, „Krakowskie Pismo Kresowe” 2009, nr 1, s. 127-128.
} 
części miasta i otoczony był wysokim ceglanym murem. Obóz funkcjonował pod kryptonimem „,szkoła” - prawdopodobnie w budynku mieściła się niegdyś placówka oświatowa. Sale więziennie znajdowały się na parterze i pierwszym piętrze trzykondygnacyjnej konstrukcji. Głównym kryterium doboru więźniów w poszczególnych salach była kolejność przyjazdu do obozu. Wyjątek stanowiła tzw. sala generalska, w której umieszczono osoby zajmujące najwyższe stanowiska w militarnych strukturach podziemnych, oraz sala dla kobiet ${ }^{4}$.

"Cele" zamykane były od zewnątrz na haczyki. Wewnątrz znajdowały się żelazne łóżka z kompletem pościeli dla każdego więźnia, stolik oraz jedna lub dwie ławki w zależności od liczby więźniów. Obiekty sanitarne były dość skromne. Stanowiły je umywalki znajdujące się w osobnych pomieszczeniach. Należy jednak pamiętać, iż budynek został jedynie zaadaptowany do przetrzymywania więźniów i nie stanowił typowej jednostki penitencjarnej. Wartym odnotowania jest również fakt, iż każdy z więźniów otrzymał do swej dyspozycji mydło oraz ręcznik. Z uwagi na brak łaźni, kąpiel odbywała się co dwa tygodnie w łaźni głównego charkowskiego więzienia NKWD. W obozie zorganizowany był stały punkt medyczny obsługiwany przez pielęgniarkę, zaś dwa razy w tygodniu w jednostce dyżurował lekarz. Więźniów wymagających hospitalizacji lub szczegółowych badań przewożono do miejscowej kliniki lub szpitala. Ponadto poddano ich obowiązkowemu szczepieniu przeciwko tyfusowi plamistemu, kilka razy zapewniono opiekę stomatologiczną, zaś potrzebującym okulistyczną ${ }^{5}$.

Mimo iż wraz z upływem czasu wyżywienie ulegało pogorszeniu, to w porównaniu racjami ilościowymi i jakościowymi obowiązującymi w tym samym czasie w trzech obozach akowskich (Borowicze, Riazań i Ostaszków) było ono nad wyraz pożywne. Dzienna racja żywieniowa chleba wynosiła $650 \mathrm{~g}$ (w innych obozach $600 \mathrm{~g}$ ). Obiad składał się z zupy i drugiego dania. Codziennie wydawano również kolację. Dwa razy - w ramach podwieczorku - więźniom wydano po kawałku czekolady i po dwa jabłka ${ }^{6}$.

Od radzieckich warunków obozowych odbiegało również zasadniczo zachowanie strażników, którzy przez 24 godziny na dobę pełnili dyżury na korytarzach. Do ich obowiązków należało także wyprowadzanie więźniów do toalety, na kilkunastominutowe spacery wokół budynku oraz na posiłki do jadalni. Jak podkreślali w swych wspomnieniach więźniowie, wartownicy (15-20 osób) byli starannie wyselekcjonowani, zachowywali dystans, egzekwowali ustalony regu-

${ }^{4}$ Biblioteka Jagiellońska Oddział Rękopisów [dalej: BJ OR], Archiwum Jerzego Polaczka [dalej: AJP], przyb. 375/01, Relacja J. Polaczka; tamże, przyb. 377/01, Rozkład więźniów w poszczególnych salach autorstwa J. Polaczka z 2 X 1984 r.

5 A. Arkusz, dz. cyt., s. 130; BJ OR, AJP, przyb. 375/01, Relacja J. Martyńczuka z 21 VIII 1985 r.; tamże, przyb. 379/01, Relacja J. Polaczka, Relacja J. Litwiniuka, Relacja B. Janeczko; tamże, przyb. 437/01, Pamiętnik W. Cholewy.

${ }^{6}$ A. Arkusz, dz. cyt., s. 130. 
lamin obozu, ale z uprzejmością odnosili się do więźniów. Stosunkowo serdeczny stosunek do kontyngentu uwięzionych mieli również poszczególni komendanci obozu? ${ }^{7}$.

Zasadniczo więźniów nie poddawano przesłuchaniom, co może dziwić biorąc pod uwagę skład kontyngentu wywodzącego się ze struktur dowódczych pionu militarnego i administracyjnego polskiego podziemia niepodległościowego. Jedynymi osobami, które przesłuchiwano, a następnie aresztowano i wysłano do więzienia butyrskiego w Moskwie, byli dwaj radiotelegrafiści z oddziału łączności „Hanka” (radiostacja AK nr 30) ${ }^{8}$. W obozie nie zorganizowano tzw. koła demokratów, a więc osób dość otwarcie manifestujących swój przyjacielski stosunek do ZSRR i nowych władz w kraju. Przygotowanie i podpisanie przez około 40 osób manifestu deklarującego taką właśnie postawę należy uznać za jednorazowe wystąpienie obliczone w głównej mierze na szybszy powrót do kraju?

Przez pierwsze dziesięć miesięcy pobytu w obozie obowiązywał zakaz przechodzenia więźniów między salami. Został on zniesiony dopiero w czerwcu 1945 r. po głodówce protestacyjnej podjętej przez Polaków (w trakcie protestu jedynym z postulatów była możliwość przechodzenia między salami w czasie wolnym). Swoboda poruszania się wpłynęła na zintensyfikowanie i zróżnicowanie działalności artystycznej i naukowej prowadzonej przez więźniów (przy akceptacji władz obozowych). Zorganizowano naukę języków obcych, kurs rolniczy i kurs podchorążych, wydawano gazetkę obozową „Semper Fidelis”, zawiązano kwartet wokalny, a także przeprowadzono konkurs przedmiotów artystycznych i użytkowych wykonanych w obozie. Wszystkie te zajęcia były w dużej mierze ucieczką od codziennej niewoli i pomagały zagospodarować czas w obliczu braku nakazu pracy $^{10}$. Brak obowiązku zatrudnienia mógł wynikać ze specyfiki obozu, a przede wszystkim z nakazu przetrzymywania więźniów w całkowitej konspiracji, co uniemożliwiało wyjście do pracy poza teren jednostki.

Biorąc pod uwagę panujące w obozie warunki bytowe, sanitarno-higieniczne, opiekę medyczną, organizację życia codziennego, a także obozowy reżim, należy stwierdzić, iż na tle radzieckich zakładów penitencjarnych obóz w Charkowie stanowił pewnego rodzaju fenomen. Najbardziej uciążliwą stroną pobytu w jednostce była jednak całkowita izolacja więźniów od świata zewnętrznego. Obowiązywał zakaz dostarczania gazet, słuchania radia, przekazywania jakichkolwiek informacji o wydarzeniach politycznych i militarnych, pisania i otrzymywania listów od najbliższych, a nawet wyglądania przez okna ${ }^{11}$.

${ }^{7}$ BJ OR, AJP, przyb. 377/01, Relacja B. Mazurka.

${ }^{8}$ A. Arkusz, dz. cyt., s. 131.

9 BJ OR, AJP, przyb. 378/01, Relacja W. Jeżewskiego z 3 V 1985 r., Relacja M. Dawidowicza z $11 \times 1986 r$.

${ }^{10}$ Tamże, przyb. 377/01, Pamiętnik B. Wyżlica, Relacja J. Polaczka, Relacja W. Jeżewskiego; tamże, przyb. 437/01, Pamiętnik $W$. Cholewy.

${ }^{11}$ A. Arkusz, dz. cyt., s. 130-131. 
Bardzo uciążliwy był również brak informacji o powodach internowania, a także dacie zwolnienia z obozu. Była to główna przyczyna protestu zorganizowanego przez osadzonych w sali generalskiej, do którego przystąpili solidarnie wszyscy więźniowie. Głodówka, bo taką formę przybrał protest, rozpoczęła się 8 czerwca 1945 r. Po paru godzinach została ona przerwana w wyniku porozumienia $\mathrm{z}$ władzami obozowymi. Na nowo podjęto ją 13 czerwca i kontynuowano do 17 czerwca. Mimo obietnic ze strony władz obozowych, nie spełniono dwóch najważniejszych postulatów protestujących, jakimi było zezwolenie na korespondencję z rodzinami oraz zwolnienie i powrót do kraju ${ }^{12}$.

W nocy z 30 na 31 grudnia 1945 r. 130-osobowy kontyngent więźniów ${ }^{13}$ załadowano do pociągu, który ruszył do Riazania. Transport przybył na miejsce 4 stycznia 1946 r. Cały nowo przybyły kontyngent ulokowano w obozie nr 178-454 w Riazaniu przeznaczonym dla kadry oficerskiej polskiego podziemia $^{14}$.

Należy przypuszczać, iż dobre warunki bytowe, jakie stworzono Polakom w Charkowie (nie licząc całkowitej izolacji od świata zewnętrznego oraz braku informacji o przyczynie internowania i dacie zwolnienia), były elementem szerszej polityki J. Stalina, wynikającej z jego pozycji wobec anglosaskich sojuszników. Instalowanie władzy komunistycznej w Polsce, reżyserowane na Kremlu, musiało dokonać się za ich zgodą. Aprobata międzynarodowa działań J. Stalina w Polsce wymagała uznania nowych władz za w pełni legalne. Zniknięcie dowódców Armii Krajowej mogło wywołać pytania aliantów o ich losy oraz przypominać wydarzenia z lat 1939-1940, w tym obawę o powtórzenie tzw. scenariusza katyńskiego. Wydaje się, iż dobre warunki bytowe stworzono na wypadek konieczności „pokazania” Polaków aliantom (być może utrzymywanie więźniów w dobrej kondycji fizycznej miało również na celu odsunięcie oskarżeń o zbrodnię katyńską - czy państwo, które tak dba o oficerów może ich również mordować?). Za tą wersją wydarzeń przemawia fakt, iż pogorszenie się warunków w obozie przypada na koniec czerwca 1945 r., kiedy już powstał Tymczasowy Rząd Jedności Narodowej ${ }^{15}$.

\section{Obóz w Riazaniu}

Obóz w Riazaniu został założony na początku 1942 r. jako specłagier nr 178. W czerwcu 1944 r. przekształcono go w stacjonarny obóz jeniecki. Składał się on wówczas z trzech podobozów. Wraz z zakończeniem II wojny światowej i wyni-

${ }_{12}$ BJ OR, AJP, przyb. 379/01, Relacja W. Jeżewskiego z 14 VII 1984 r., Relacja W. Modzelewskiego z 17 III 1984 r., Relacja J. Pasadyna; tamże, przyb. 437/01, Pamiętnik W. Cholewy.

13 Jedna osoba zmarła na zawał serca $\mathrm{w}$ trakcie pobytu w obozie, jedna przebywała wówczas w szpitalu, zaś dwie osoby zostały wcześniej aresztowanie i odesłane do moskiewskich Butyrek.

${ }_{14}$ A. Arkusz, dz. cyt., s. 133.

15 Tamże, s. 133-134; BJ OR, AJP, przyb. 377/01, Relacja J. Polaczka. 
kającym z niego masowym napływem jeńców obóz uległ znacznej rozbudowie. W maju-czerwcu 1945 r. powstało aż 11 nowych podobozów. Łącznie obóz liczył wówczas 14 jednostek o ogólnej pojemności 14 tys. osób. W 1946 r., na kanwie przekształceń organizacyjno-strukturalnych, nastąpiła zmiana numeru obozu na 454, a siedziba jego zarządu znajdowała się w Kaniszczewskich Wysiełkach ${ }^{16}$.

Kontyngent jeńców wojennych przetrzymywanych w obozie uzupełniali internowani obywatele polscy, których zaczęto umieszczać w Riazaniu od sierpnia 1944 r. Transporty z internowanymi przybywały do obozu aż do 1947 r. (niektóre liczyły zaledwie po parę osób). Największa fala obywateli polskich (1516 osób) przybyła w kwietniu 1945 r. z obozu nr 41 w Ostaszkowie. Ogółem w latach 1944-1947 przez obóz przeszło 2627 internowanych obywateli polskich, w tym 49 kobiet oraz troje dzieci urodzonych w obozie. Najliczniejszą grupę wśród nich stanowili oficerowie i żołnierze AK, głównie ze struktur lwowskich, wileńskich, lubelskich i białostockich. W skład drugiej grupy wchodziły osoby cywilne zatrzymane pod zarzutem współpracy z niemieckim okupantem, zaś w skład trzeciej przedstawiciele administracji cywilnej Polskiego Państwa Podziemnego ${ }^{17}$.

Do marca 1945 r. wszystkie nowo przybyłe transporty z internowanymi Polakami (ogółem 706 osób) umieszczano w podobozie w Kaniszczewskich Wysiełkach. Podobóz składał się m.in. z baraków mieszkalnych, kuchni, pralni, łaźni, fryzjerni, izb dezynfekcyjnych oraz karceru. Otoczony był wysokim drewnianym płotem nad którym znajdowały się cztery rzędy drutu kolczastego. W każdym rogu podobozu ulokowane były wieżyczki strażnicze z uzbrojonymi wartownikami. Wzdłuż wewnętrznej strony ogrodzenia przebiegała tzw. zakazana zona - jej przekroczenie groziło natychmiastowym zastrzeleniem. W jednostce panowały tragiczne warunki bytowe i sanitarne wynikające w dużej mierze z nieprzygotowania obozu do przyjęcia tak dużej liczby osób. Polaków umieszczono w małych barakach pozbawionych oświetlenia i ogrzewania. Internowani spali na gołych pryczach. Brakowało im sienników oraz odzieży ${ }^{18}$.

Fatalny był również system odżywiania. Początkowo realizowano go w dwóch normach - oficerskiej oraz podoficerskiej, do której zaliczono również szeregowców oraz osoby cywilne. Zgodnie z normą oficerską dzienna racja białego chleba wynosiła $600 \mathrm{~g}$; pozostałym wydawano ciemny chleb w takiej samej ilości. Po upływie półtora miesiąca przebywania w obozie wszystkim więźniom - niezależnie od przysługującej im normy - wydawano tylko ciemny chleb. Chleb stanowił podstawę tzw. suchego prowiantu dostarczanego na śniadanie, w skład którego

${ }^{16}$ A. Arkusz, Obywatele polscy w obozie NKWD-MWD ZSRR $n r$ 178-454 w Riazaniu $w$ latach 1944-1947, Kraków 2010, s. 203, 210-211, 214, 218, 226.

17 Tamże, s. 243-255; Indeks Represjonowanych, t. 13, Uwięzieni w Ostaszkowie i Riazaniu, red. A. Dzienkiewicz, A. Gurjanow, Warszawa 2002, s. 19.

${ }_{18}$ BJ OR, AJP, przyb. 328/01, Relacja W. Wermana z 13 IV 1985 r., Relacja J. Strzęciwilka; W. Kiewlicz, Riazań-Diagilewo, Warszawa 1995, s. 8. 
wchodziła również kostka margaryny (jedna na cztery osoby), $40 \mathrm{~g}$ cukru oraz 10 sztuk papierosów i zapałek (tylko dla oficerów). Poza suchym prowiantem na śniadanie więźniowie otrzymywali 0,75 1 zupy (bardzo rzadka, głównie z kapusty lub liści buraczanych). Tą samą zupę wydawano również na pierwsze danie obiadu; drugim daniem była najczęściej kasza, kartofle lub kapusta (od 150 do 200 g). Od listopada 1944 r. praktycznie nie wydawano kolacji ${ }^{19}$.

W podobozie panowały również tragiczne warunki sanitarne. Kąpiel odbywała się raz na dwa tygodnie. W trakcie jej trwania każdy z więźniów otrzymywał wiaderko gorącej wody (woda zimna była dostarczana w dowolnej ilości z kranu) oraz mydło wielkości dwóch kostek cukru. W podobozie nie istniał żaden system opieki medycznej. Brakowało lekarstw, personelu medycznego oraz miejsc rekonwalescencji i hospitalizacji. Nie obowiązywał żaden regulamin. Codziennie odbywały się przesłuchania ${ }^{20}$.

5 marca 1945 r. w obozie rozpoczęła się głodówka będąca protestem przeciwko złym warunkom bytowym i sanitarnym, zakazowi korespondencji z rodzinami, zmuszaniu do pracy przy wyrębie lodu (przy bardzo niskich temperaturach i bez dodatkowych ubrań) oraz braku informacji o przyczynach internowania, przetrzymywania w obozie, statusie uwięzionych i dacie zwolnienia. Do protestu przyłączyli się prawie wszyscy z internowanych, oprócz chorych i osłabionych. 8 marca 1945 r., czwartego dnia protestu, władze obozowe przystąpiły do zdecydowanych działań. Więźniów poddano bowiem procedurze przymusowego karmienia poprzez sondę wprowadzaną do przełyku. Akcję nasilono w kolejnych dwóch dniach protestu. Z uwagi na wyczerpanie „strajkujących” oraz brak nadziei na porozumienie się z władzami obozowymi, 12 marca 1945 r. przerwano głodówkę, natomiast władze obozowe wydały więźniom sienniki, odpowiednie ubrania, a także obiecały poprawę jakości wyżywienia. Nie wyrażono jednak zgody na korespondencję z rodzinami, a także nie podano informacji o przyczynie internowania i dacie zwolnienia. 15 kwietnia 1945 r. całą grupę Polaków przeniesiono do podobozu w Diagilewie. Od tego czasu umieszczano w nim również wszystkie transporty, jakie przybyły z internowanymi ${ }^{21}$.

Podobóz diagilewski otaczały zasieki z drutu kolczastego, wewnątrz znajdowały się baraki mieszkalne oraz budynki administracyjno-gospodarcze, w tym warsztaty. W Diagilewie istniały lepsze warunki bytowe, sanitarno-higieniczne, lepsza opieka medyczna, a także system pracy wykonywanej przez więźniów. W obozie obowiązywał regulamin skrupulatnie egzekwowany przez władze obozowe. Internowani pracowali zarówno na terenie obozu, jak i poza jego granicami. Brygady robocze przeznaczone do prac wewnątrzobozowych wykonywały

\footnotetext{
${ }^{19}$ BJ OR, AJP, przyb. 394/01, Relacja K. Kozłowicza, Relacja F. Robaka, Relacja J. Szota.

20 A. Arkusz, Obywatele polscy w obozie NKWD-MWD..., s. 292.

${ }^{21}$ Tamże, s. 293-298.
} 
głównie obowiązki związane z funkcjonowaniem jednostki oraz szeregiem prac porządkowych - pracowano m.in. w kuchni, piekarni, łaźni, pralni, magazynach, fryzjerni oraz przy wywozie nieczystości. Latem 1945 r. rozpoczęto pracę w obozowych warsztatach - krawieckim, szewskim, ślusarsko-mechanicznym, stolarskim oraz wikliniarskim. Prace te mogli wykonywać szeregowcy oraz podoficerowie (z wyjątkiem pracy w szpitalu) zaakceptowani przez władze obozowe. Za przekroczenie ustanowionej normy przysługiwało dodatkowe wyżywienie w postaci $200 \mathrm{~g}$ chleba lub porcji zupy ${ }^{22}$.

Największą popularnością cieszyła się jednak praca wykonywana poza terenem obozu, która dawała możliwość wysyłania listów (nielegalnie) oraz nabycia różnych przedmiotów sprzedawanych następnie miejscowej ludności lub przemycanych do obozu. Jednak z uwagi na prawdopodobieństwo ucieczki lub próby nawiązania korespondencji z rodzinami, selekcja pracowników do prac wykonywanych poza terenem jednostki była dość szczegółowa. Ogółem poza terenem obozu pracowało 15-20 brygad. Szczególnie miejsce zajmowała tzw. „brygada Kecz" - licząca ponad 60 osób i pracująca dla potrzeb Miejskiego Przedsiębiorstwa Gospodarki Mieszkaniowej Zarządu NKWD w Riazaniu. Brygada wykonywała różnorakie prace budowlane oraz naprawcze obiektów mieszkalnych, gospodarczych, administracyjnych oraz miejskich dróg. Za pracę wykonywaną poza terenem obozu również przysługiwało dodatkowe wyżywienie ${ }^{23}$.

W Diagilewie wyżywienie było lepsze niż w Kaniszczewskich Wysiełkach. Mimo iż oficjalnie obowiązywały trzy normy żywieniowe - oficerska, podoficerska (obejmująca również szeregowców i osoby cywilne) oraz norma ustanowiona dla chorych przebywających w szpitalu - w rzeczywistości skład produktów przynależnych normie oficerskiej i podoficerskiej był taki sam, analogicznie jak przydział wagowy wydawanych posiłków (posiłki oficerskie było nieco gęstsze). Na śniadanie każdemu z więźniów wydawano 0,751 zupy. Obiad był dwudaniowy. Na pierwsze danie podawano tę samą zupę, co na śniadanie, zaś na drugie 250-gramową porcję kaszy, ziemniaków lub kapusty. Kolację stanowił kubek kawy. W skład suchego prowiantu przynależnego normie oficerskiej wchodziło $300 \mathrm{~g}$ chleba białego, $300 \mathrm{~g}$ chleba ciemnego, $40 \mathrm{~g}$ cukru, $40 \mathrm{~g}$ thuszczu, 15 sztuk papierosów lub $10 \mathrm{~g}$ machorki (tytoniu). Norma podoficerska składała się z $600 \mathrm{~g}$ chleba ciemnego, $30 \mathrm{~g}$ cukru, $30 \mathrm{~g}$ tłuszczu, 10 sztuk papierosów lub pięciu g machorki (od września 1945 r. papierosy wydawano tylko dla pracujących). Normy żywnościowe były niewystarczające, a co najważniejsze nie dostarczały

${ }^{22}$ BJ OR, AJP, przyb. 383/01, Relacja M. Stowik z 5 III 1985 r., Relacja M. Sierocińskiego, Relacja S. Sudnickiego, Relacja W. Wermana z 28 VIII 1985 r., Relacja K. Kozłowicza, Relacja M. Klimczuka z 27 X 1985 r., Relacja R. Skopala, Relacja W. Krajewskiego, Relacja J. Błażka z sierpnia 1985 r., Relacja E. Mieczkowskiego, Relacja Z. Skrzeka, Relacja T. Litwińskiego.

${ }^{23}$ Szerzej zob. A. Arkusz, Obywatele polscy w obozie NKWD-MWD..., s. 313-317. 
potrzebnych organizmowi wartości odżywczych, stąd też często pojawiały się choroby związane z niedożywieniem ${ }^{24}$.

Opiekę medyczną w obozie zorganizował doktor Alfred Paczkowski, który przybył do Diagilewa we wrześniu 1945 r. Mimo permanentnego braku odpowiednich narzędzi i aparatury, a także lekarstw, szpital pomagał chorym - w miarę swych możliwości, a nawet wykonywał lżejsze operacje. Z pomocy polskich lekarzy korzystali również radzieccy pracownicy obozu. W latach 1945-1947 na terenie obozu zmarło ogółem 30 osób. Łączna liczba zgonów odnotowanych wśród polskiego kontyngentu wyniosła 53 osoby; część z nich zmarła w różnych jednostkach więziennych i szpitalnych po odesłaniu z Diagilewa ${ }^{25}$.

W Diagilewie wśród więźniów rozwinęła się na szeroką skalę działalność samokształceniowa i kulturalna (program zajęć musiał uzyskać akceptację wydziału politycznego komendantury). W podobozie powstały grupy zajmujące się nauką języków obcych (angielski, rosyjski) oraz prowadzące różnego rodzaju szkolenia i kursy z zakresu leśnictwa, rolnictwa, muzyki i pedagogiki. Poza tym prowadzono szkolenia $z$ buchalterii i stenografii, księgowości i handlu zagranicznego oraz wykłady z biologii i chemii. Ukazywała się redagowana przez uwięzionych gazetka satyryczna „Jeż obozowy”, powstał 80-osobowy zespół teatralny „Nasza Buda”, a także kilkunastoosobowa orkiestra oraz chóry. Wszystkie te przedsięwzięcia były ucieczką od obozowej rzeczywistości, a dla oficerów (po przepracowaniu określonej liczby godzin) szansą na zdobycie dodatkowego wyżywienia (w obozach GUPWI istniał zakaz pracy fizycznej dla kadry oficerskiej $)^{26}$.

W obozie dość systematycznie prowadzono przesłuchania wśród więźniów. Ogółem aresztowano 82 osoby, które następnie wywieziono do więzienia w Riazaniu i skazano, w tym cztery na karę śmierci (wyroki wykonano) ${ }^{27}$. Sporadycznie zaś władze obozowe przeprowadzały wśród uwięzionych szkolenia polityczno-wychowawcze w duchu ideologii komunistycznej, głównie za pośrednictwem działającego na terenie obozu „koła demokratów” zrzeszającego prawdopodobnie 52 osoby. Przygotowaną przez nich deklarację poparcia dla nowego rządu w Polsce podpisało 528 internowanych. Podpisów pod tym dokumentem nie można interpretować jednoznacznie jako odzwierciedlających nastawienie ich sygnatariuszy do przemian politycznych w kraju. Był to raczej akt obliczony na szybszy powrót do kraju. Świadczy o tym chociażby fakt, iż do głodówki, która wybuchła jako protest przeciwko długoletniemu przetrzymywaniu, nie przystąpiła grupa

${ }^{24}$ BJ OR, AJP, przyb. 381/01, Relacja A. Pawlickiego, Relacja W. Krajewskiego z 20 XII 1986 r., Relacja W. Bohra z 10 X 1985 r., Relacja T. Litwińskiego z 10 XI 1985 r., Relacja J. Polaczka.

${ }_{25}$ A. Arkusz, Obywatele polscy w obozie NKWD-MWD..., s. 264.

26 Tamże, s. 326-336.

27 Tamże, s. 271. 
ok. 50-70 internowanych (w zdecydowanej większości „demokratów”) na niewiele ponad 1,5 tys. osób przebywających wówczas w obozie ${ }^{28}$.

Głodówka rozpoczęła się 29 czerwca 1947 r. Najważniejszym żądaniem internowanych było natychmiastowe zwolnienie i powrót do kraju. Protestowano również przeciwko zakazowi korespondencji, częstym przesłuchaniom, bezpodstawnym aresztowaniom, brakowi kontaktu z polskimi władzami - mimo upływu ponad dwóch lat od zakończenia wojny, a także pogorszeniu się wyżywienia. Trzeciego dnia głodówki (1 lipca) władze obozowe przystąpiły do przymusowego odżywiania więźniów (pokarm - mannę - podawano poprzez gumowy wąż i lejek). Przymusowe karmienie zastosowano również w szpitalu w Skopinie (podczas jednej z takich akcji zmarł gen. K. Tumidajski). Głodówkę przerwano 5 lipca. Internowanym obiecano, że będą oni intensywnie odżywiani, a po gruntownym przebadaniu lekarskim odesłani do kraju (zamiast tego cały kontyngent wysłano do innych obozów) ${ }^{29}$.

Pierwsze zwolnienia z obozu nastąpiły w styczniu 1945 r. Obóz opuściło wówczas 86 osób. W następnym roku z obozu zwolniono 848 internowanych. Kolejne zwolnienia miały miejsce w czerwcu-lipcu 1947 r. (po głodówce protestacyjnej). Cały znajdujący się wówczas w obozie kontyngent podzielono na pięć grup, z czego cztery wywieziono do kolejnych obozów jenieckich: nr 158 w Czerepowcu (103 osoby), nr 437 w Bogorodskoje (356 osób), nr 171 w Susłongier (342 osoby) i nr 270 w Borowiczach (421 osób). Ostatnią grupę (295 osób) we wrześniu 1947 r. skierowano do Polski ${ }^{30}$.

\section{Obóz w Borowiczach}

Obóz NKWD nr 270 w Borowiczach utworzono we wsi Szybotowo w rejonie borowickim w obwodzie nowogrodzkim w 1942 r. jako frontowy obóz przyjęciowo-przesyłowy. Dwa lata później przekształcono go w stacjonarny obóz jeniecki z siedzibą zarządu we wsi Jogła w rejonie opoczyńskim. Pod koniec 1942 r. zarząd obozu przeniesiono z kolei do miasta Borowicze. Przekształcenia organizacyjno-strukturalne związane były z rozbudową obozu, która przybrała na sile po zakończeniu II wojny światowej. Wtedy też nastąpił największy w historii obozu napływ jeńców wojennych: na początku 1946 r. obóz liczył już 18 podobozów ${ }^{31}$.

${ }^{28}$ BJ OR, AJP, przyb. 389/01, Relacja T. Kaczmarka z 24 II 1986 r., Relacja J. Habeli z października 1986 r., Relacja K. Kozłowicza, Relacja S. Szostakiewicza, Relacja M. Stawomirskiego, Relacja A. Pietrzaka, Relacja J. Litwiniuka.

${ }^{29}$ Szerzej zob. A. Arkusz, Obywatele polscy w obozie NKWD-MWD..., s. 351-373.

${ }^{30}$ Dane nie uwzględniają indywidualnych lub kilkuosobowych zwolnień z obozu; Indeks Represjonowanych, t. 13, s. 40-43.

${ }^{31}$ A. Arkusz, Położenie obywateli polskich $w$ obozie NKWD $n r 270$ w Borowiczach $w$ latach 1944-1949, [w:] „Studia Historyczne” 2008, z. 1 (201), s. 71-72. 
Kontyngent więźniów, złożony w przeważającej większości z jeńców, uzupełniali internowani obywatele polscy, których zaczęto umieszczać w obozie pod koniec 1944 r. Pierwsze transporty z internowanymi przybyły do Borowicz w listopadzie-grudniu tamtego roku i liczyły łącznie 4893 osoby. W przeważającej większości byli to szeregowi żołnierze Armii Krajowej i Batalionów Chłopskich aresztowani w październiku i listopadzie 1944 r. na terenach województw: lubelskiego, warszawskiego, kieleckiego, rzeszowskiego i częściowo białostockiego. Kolejne grupy Polaków przywieziono dopiero w drugiej połowie 1947 r. Byli to internowani przetrzymywani uprzednio w Kutaisi (467 osób) oraz w Riazaniu (421 osób). Grupy te różniły od poprzednich nie tylko liczebnością, ale również składem internowanych. Osoby przybyłe z Kutaisi w dokumentach NKWD określano początkowo jako podejrzane o członkostwo w Armii Krajowej, zaś z chwilą dotarcia do obozu zakwalifikowane do tej kategorii, natomiast osoby przetransportowane z obozu riazańskiego były w dużej mierze związane z konspiracją cywilną. Łącznie w Borowiczach w latach 1944-1949 przetrzymywano 5795 przedwojennych obywateli polskich (w tym dziewięcioro dzieci urodzonych w obozie) ${ }^{32}$.

Polaków umieszczono na terenie pięciu podobozów zlokalizowanych w: Borowiczach, Jogle, Opocznie, Szybotowie, Ustie i w jednej podkomandirowce o nazwie Kawanka. W każdej z tych jednostek panowały tragiczne warunki bytowe związane z dużej mierze z olbrzymią liczbą ulokowanych tam więźniów. Z uwagi na przepełnienie więźniowie zmuszeni byli spać po kilka osób na pryczy, w najgorszym zaś wypadku na podłodze. Wyposażenie baraków mieszkalnych było bardzo skromne. Składało się na nie kilka rzędów prycz pozbawionych na ogół sienników oraz piece - najczęściej nieużywane w okresie zimowym z uwagi na brak opału. Cześć baraków była do połowy wkopana w ziemię. Zaletą takich ziemianek było zatrzymywanie uchodzącego z ich wnętrza ciepła, wadą zaś ulokowane bardzo wysoko okna przepuszczające w ograniczonym zakresie promienie słoneczne. Poza barakami mieszkalnymi na terenie obozu znajdowały się również: łaźnia, kuchnia, szpital z ambulatorium, karcer, magazyny, warsztaty oraz latryny ${ }^{33}$.

System zabezpieczeń i związana z nim ochrona obozu były niemal identyczne jak w obozie w Riazaniu. Podobozy otoczone były wysokim płotem lub zasiekami z drutu kolczastego. Na każdym rogu podobozów znajdowały się wieżyczki strażnicze z uzbrojonymi wartownikami. Wzdłuż ścian przebiegała tzw. zakazana zona - wejście na jej teren groziło śmiercią z rąk strażnika. Symbolem obozowego

${ }^{32}$ Taż, Polacy internowani $w$ obozie NKWD w Borowiczach w latach 1944-1949, [w:] „Pamięć i Sprawiedliwość" 2006, nr 2 (10), s. 213-216; Indeks Represjonowanych, t. 4, Uwięzieni w Borowiczach, red. A. Dzienkiewicz, A. Gurjanow, Warszawa 1997, s. 11.

${ }_{33}$ BJ OR, AJP, przyb. 372/01, Szkic S. Szostakiewicza; tamże, przyb. 374/01, Szkic A. Kaleczyńskiego. 
reżimu był karcer, w którym umieszczano więźniów naruszających regulamin lub których władze obozowe uznały za winnych popełnienia jakiegoś zabronionego czynu ${ }^{34}$.

Normy żywieniowe były tragicznie niskie. We wszystkich podobozach były one niemal identyczne, choć ich wielkość zależała w pewnym stopniu od rodzaju wykonywanej pracy oraz wypełniania obowiązujących norm, za co można było otrzymać od 200 do $400 \mathrm{~g}$ chleba dziennie. Śniadanie składało z pół litra zupy (z kaszy jęczmiennej bądź jaglanej okraszanej margaryną), czarnego chleba wydawanego w ilości $600 \mathrm{~g}$, płaskiej łyżki cukru - ok. $17 \mathrm{~g}$ oraz dwóch dkg margaryny lub smalcu. Obiad nie był wydawany w obozie; niepracujący dzielili najczęściej dzienną porcję chleba na śniadanie - 200 g oraz kolację - 400 g. Ostatni ,posiłek” w ciągu dnia stanowiła zupa ugotowana z kartofli, kapusty, brukwi lub obierek kartoflanych, często z rybami. Jedzenie było zatem niewystarczające i nie dostarczało potrzebnych organizmowi wartości odżywczych. Uległo ono nieznacznej poprawie dopiero w 1947 r., choć nadal nie spełniało podstawowych wymogów żywieniowych ${ }^{35}$.

W obozie borowickim każdy więzień zobligowany był do wykonywania określonej pracy. Jej rodzaj związany był w dużej mierze ze „specjalizacją” gospodarczą każdego z podobozów. Najlżejsze prace wykonywano w Jegolsku pełniącym rolę podobozu „zdrowotnego" dla całego kontyngentu uwięzionych. Uwzględniano tam zatem proces rekonwalescencji więźniów. Podczas pobytu w tej jednostce pracowano głównie w miejscowych kołchozach lub wykonywano zadania związane $\mathrm{z}$ obsługą podobozu. Najcięższe warunki pracy panowały $\mathrm{w}$ Ustie (podobóz szachtowy), w którym osadzeni pracowali w okolicznych kopalniach. Praca była w systemie trzyzmianowym, po osiem godzin dziennie, bez odpowiednich narzędzi, ubrań, systemu zabezpieczeń i należytego wyżywienia. Wpływała zatem fatalnie na stan zdrowia uwięzionych. Poza pracami związanymi z obsługą obozu (pralnia, łaźnia, kuchnia, warsztaty, itp.) internowali byli zatrudniani m.in. w pobliskich fabrykach, przy wydobywaniu z rzeki spławionego drewna lub torfu, wykonywali prace budowlane itp. ${ }^{36}$

Na tragiczne warunki bytowe wpływał również fatalny system opieki medycznej. W obozowych szpitalach brakowało podstawowych lekarstw, personelu oraz odpowiedniej ilości łóżek. Najczęstszą chorobą wśród więźniów była dystrofia, szkorbut, zapalenie płuc, diureza, egzema, gruźlica oraz świerzb. Tragiczne były również warunki sanitarno-higieniczne. Plagą były wszy i pluskwy. Rzadko korzystano z łaźni. Pierwsza kąpiel odbyła się po dwóch-trzech miesiącach od przybycia do obozu pierwszych grup internowanych Polaków. Każdy więzień otrzymał wtedy cztery litry wody w drewnianym wiaderku oraz kawałek mydła

\footnotetext{
${ }^{34}$ BJ OR,AJP, przyb. 373/01, Relacja M.Dawidowicza, Relacja Z. Kozów, Relacja S. Puchalskiego.

35 A. Arkusz, Polożenie obywateli polskich..., s. 78-79.

36 Tamże, s. 81-84.
} 
wielkości kostki cukru - taka ilość wody musiała wystarczyć zarówno na kąpiel, jak i na wypranie swoich ubrań3 ${ }^{37}$.

Fatalny system odżywiania, brak odpowiedniej opieki medycznej oraz ciężka, wyczerpująca praca wpływały bezpośrednio na tragiczny stan zdrowia więźniów. Wysoka śmiertelność oraz wysoki procent osób niezdolnych do pracy doprowadziły do wewnątrzobozowej kontroli przeprowadzonej 5 października $1945 \mathrm{r}$. przez zastępcę szefa 1. Zarządu GUPWI NKWD ZSRR płk. Mielnika (na polecenie zastępcy ludowego komisarza spraw wewnętrznych ZSRR gen. Czernyszowa). Za główne przyczyny niskiej wydajności pracy (ustalone normy wykonywane były w 25-70\%) płk Mielnik uznał brak należytego technicznego kierownictwa pracy, złą ewidencję pracy, niedostarczanie Polakom dodatkowego wyżywienia (10-godzinna przerwa między posiłkami), a także brak zaopatrzenia pracujących pod ziemią $\mathrm{w}$ odpowiednią odzież i obuwie gumowe, co powodowało, iż większość z nich wracała do obozu w mokrym obuwiu i ubraniu ${ }^{38}$.

W 1945 r. w obozie borowickim wskaźnik umieralności wyniósł 11,5\%. Zmarło wtedy od 532 do 534 obywateli polskich (ponad 81\% w okresie od stycznia do czerwca), z czego aż 182 osoby zmarły w Ustie. Do połowy 1946 r. zmarło łącznie 617 osób. W 1946 r. wskaźnik umieralności znacznie się obniżył i wyniósł $2,8 \%$. W kolejnych latach następował jego dalszy spadek. W 1947 r. - 0,6\%, zaś w 1948 r. - 0,2\%. Wskaźniki te świadczą pośrednio o zmianie obozowego reżimu i poprawie warunków bytowych ${ }^{39}$.

W obozie prowadzone były dość często przesłuchania. Łącznie aresztowano i wywieziono do więzienia borowickiego 13 osób $^{40}$. W Jegolsku działała grupa „demokratów”, jednak nie wiadomo, ilu liczyła członków. Redagowana przez nich ścienna gazetka obozowa miał wyraźnie proradziecki profil ${ }^{41}$. W Borowiczach więźniowie prowadzili również działalność artystyczną, choć na znacznie mniejszą skalę. Rozkwit obozowego życia kulturalnego nastąpił dopiero w $1947 \mathrm{r}$. z chwilą przybycia grupy riazańskiej, która odtworzyła repertuar „Naszej Budy”42.

W styczniu-lutym 1946 r., na fali zwolnień szeregowych żołnierzy Armii Krajowej, do kraju wysłano 3466 osób; 810 osób niepodlegających repatriacji odesłano w lipcu tamtego roku do obozu jenieckiego nr 531 pod Swierdłowskiem na Uralu, a tam podzielono i przetransportowano dalej. Większość Polaków przywiezionych z obozu riazańskiego zwolniono w 1947 r. na kanwie prowadzonej wówczas repatriacji oficerskiej i kierowniczej kadry organizacji konspiracyj-

${ }^{37}$ W. Fijewski, Niedobre dni, Wrocław 1983, s. 3; Księga Borowiczan, t. 1, Gdynia 1992, s. 53-54.

${ }^{38}$ Raport pokontrolny zastępcy szefa 1. Zarzadu GUPWI NKWD ZSRR ptk. Mielnika dla zastępcy ludowego komisarza spraw wewnętrznych ZSRR gen. W. Czernyszowa o sytuacji w obozie NKWD nr 270 w Borowiczach, 5 X 1945 r., [w:] NKWD o Polsce..., s. 111-113.

${ }^{39}$ Szerzej zob. A. Arkusz, Polacy internowani w obozie NKWD..., s. 216-218.

40 Tamże, s. 224-225.

${ }^{41}$ Ksiega Borowiczan, t. 5, Warszawa 2004, s. 70.

${ }^{42}$ A. Arkusz, Polożenie obywateli polskich..., s. 86-87. 
nych. Pozostałych umieszczono w podobozie w Szybatowie. Razem z grupą z Kutaisi wrócili oni do Polski w okresie od końca 1947 r. do wiosny 1949 r. ${ }^{43}$

\section{Podsumowanie}

Biorąc pod uwagę warunki bytowe, jakie stworzono internowanym obywatelom polskim w obozach podporządkowanych Głównemu Zarządowi do Spraw Jeńców Wojennych i Osób Internowanych NKWD (od 1946 r. - MWD) ZSRR, należy uznać, iż zależały one w olbrzymim stopniu od składu osobowego kontyngentu uwięzionych. W obozie w Riazaniu, w którym przetrzymywano głównie kadrę oficerską polskiego podziemia niepodległościowego, warunki bytowe (poza podobozem w Kaniszczewskich Wysiełkach) były o wiele lepsze niż w obozie w Borowiczach, gdzie więziono przede wszystkim szeregowych żołnierzy Armii Krajowej i Batalionów Chłopskich. Dotyczyło to zarówno systemu wyżywienia, warunków sanitarno-higienicznych, opieki medycznej, a także rodzaju pracy wykonywanej przez więźniów. Poza tym w obozie riazańskim na szeroką skalę rozwinęła się wśród osadzonych działalność kulturowa i samokształceniowa, co wiązać należy $\mathrm{z}$ dużą liczbą przetrzymywanych $\mathrm{w}$ nim oficerów, którzy zgodnie z obowiązującymi w systemie GUPWI przepisami, nie mogli wykonywać pracy fizycznej.

Najlepsze warunki bytowe funkcjonowały w obozie charkowskim, który organizacyjnie różnił się zasadniczo od typowych radzieckich jednostek penitencjarnych. Dobre warunki bytowe, jakie stworzono Polakom w obozie w Charkowie, były elementem szerszej polityki J. Stalina i uległy pogorszeniu po osiągnięciu przez przywódcę ZSRR poparcia aliantów dla instalowania nowej władzy w Polsce.

Mimo różnic w codziennym funkcjonowaniu obozów, w każdej z omówionych jednostek internowani obywatele polscy byli pozbawieni podstawowych informacji dotyczących przyczyn zatrzymania i wywiezienia do obozu, a także przewidywanej daty zwolnienia.

\section{Aleksandra Arkusz}

\section{EVERYDAY LIFE OF POLISH CITIZENS IN SELECTED CAMPS IN THE USSR IN THE YEARS 1944-1949}

$\mathrm{W}$ ith the re-entry of the Red Army into Poland in 1944, another phase of Soviet repressions began. The internees (deprived of liberty without being sentenced by any judicial body) members of the Polish Independence Underground were held mainly in the camps subordinated to GUPVI NKVD. They were camps in Ostashkov, Ryazan and Borovichy, among many others. A special role was played by the „Smersh" counter-intelligence camp in Kharkov, to which highranking representatives of various divisions of the independence underground had been sent.

${ }^{43}$ Taż, Polacy internowani w obozie NKWD..., s. 225-228. 
Considering living conditions prevailing in those camps, it should be acknowledged that they depended enormously on the composition of the prisoners. In the camp in Ryazan, where mainly officers of the independence underground were kept, the living conditions were much better than in the camp in Borovichy, where the rank-and-file soldiers of the Home Army and the Peasants' Battalions were imprisoned. This concerned a food system, sanitary and hygienic conditions, medical care, as well as type of work performed by the prisoners. The best living conditions were in the Kharkov camp, although the internees were completely isolated from the outside world.

Słowa kluczowe: deportacja, radzieckie obozy pracy, zesłanie

Keywords: deportation, Soviet labor camps, exile

\section{BIBLIOGRAFIA}

\section{Źródla archiwalne:}

Biblioteka Jagiellońska (Oddział Rękopisów)

Archiwum Jerzego Polaczka, przyb. 328/01, 372/01, 373/01, 374/01, 375/01, 377/01, 378/01, 379/01, $381 / 01,383 / 01,389 / 01,394 / 01,437 / 01$.

\section{Źródła publikowane:}

NKWD i polskie podziemie 1944-1945. Z „teczek specjalnych” J.W. Stalina, red. A.F. Noskowa, A. Fitowa, Kraków 1998.

NKWD o Polsce i Polakach. Rekonesans archiwalny, red. W. Materski, A. Paczkowski, Warszawa 1996.

\section{Pamiętniki i wspomnienia:}

Fijewski W., Niedobre dni, Wrocław 1983.

Kiewlicz W., Riazań-Diagilewo, Warszawa 1995.

\section{Opracowania:}

Arkusz A., Obywatele polscy w obozie kontrwywiadu „Smiersz” w Charkowie w latach 1944-1945, [w:] „Krakowskie Pismo Kresowe", R. 1 (2009).

Arkusz A., Obywatele polscy w obozie NKWD-MWD ZSRR nr 178-454 w Riazaniu w latach 1944-1947, Kraków 2010.

Arkusz A., Polacy internowani w obozie NKWD w Borowiczach w latach 1944-1949, [w:] „Pamięć i Sprawiedliwość" 2006, nr 2 (10).

Arkusz A., Polożenie obywateli polskich w obozie NKWD $n r 270$ w Borowiczach w latach 1944-1949, [w:] „Studia Historyczne” 2008, z. 1 (201).

Indeks Represjonowanych, t. 4, Uwięzieni w Borowiczach, red. A. Dzienkiewicz, A. Gurjanow, Warszawa 1997.

Indeks Represjonowanych, t. 13, Uwięzieni w Ostaszkowie i Riazaniu, red. A. Dzienkiewicz, A. Gurjanow, Warszawa 2002.

Kołakowski P., NKWD i GRU na ziemiach polskich 1939-1945, Warszawa 2002.

Księga Borowiczan, t. 1, Gdynia 1992; t. 5, Warszawa 2004.

Represje sowieckie wobec Polaków i obywateli polskich, oprac. S. Ciesielski, W. Materski, A. Paczkowski, Warszawa 2002. 